\title{
FAKTOR RISIKO YANG BERHUBUNGAN DENGAN KEJADIAN BAYI BERAT LAHIR RENDAH DI KECAMATAN SEMAMPIR SURABAYA
}

\author{
Risk Factors Associated with Low Birth Weight at Semampir District, Surabaya \\ Amima Fajriana ${ }^{1}$, Annas Buanasita ${ }^{2}$ \\ ${ }^{1}$ Program Studi S1 Ilmu Gizi, Fakultas Kesehatan Masyarakat Universitas Airlangga, Surabaya \\ ${ }^{2}$ Akademi Gizi Surabaya \\ E-mail: amimafajriana@gmail.com
}

\begin{abstract}
ABSTRAK
Bayi Berat Lahir Rendah (BBLR) adalah salah satu penyebab terbesar kematian neonatal di Indonesia. Prevalensi BBLR di Kecamatan Semampir Surabaya cenderung meningkat yaitu 5,74\% di tahun 2013 menjadi 13,65\% pada tahun 2015. BBLR disebabkan oleh multifaktor yaitu faktor internal seperti janin, plasenta dan maternal, dan juga faktor eksternal misalnya gaya hidup dan lingkungan. Penelitian ini bertujuan untuk menganalisis hubungan antara usia ibu saat hamil, usia gestasi, ukuran Lingkar Lengan Atas (LILA), kadar hemoglobin (Hb) dan status paparan asap rokok dengan kejadian BBLR di Kecamatan Semampir, Surabaya. Responden pada penelitian ini adalah sebagian ibu di Kecamatan Semampir yang melahirkan tahun 2016. Desain penelitian yang digunakan adalah kasus kontrol. Besar sampel penelitian adalah 22 ibu dari kelompok kontrol dan 22 ibu dari kelompok kasus. Hasil analisis deskriptif secara berturut-turut menunjukkan bahwa pada kelompok kasus $(40,6 \%)$ dan kontrol $(13,6 \%)$ hamil di usia bukan reproduktif sehat. $59,1 \%$ dan $18,1 \%$ ibu melahirkan ketika usia gestasinya $<37$ minggu. $41 \%$ dan $9,1 \%$ ibu mengalami KEK (LILA $<23,5) .40,9 \%$ dan $22,7 \%$ ibu anemia. Selain itu, $90,9 \%$ dan 77,2\% ibu terpapar asap rokok. Analisis Chi Square dengan $\alpha=0,05$ menunjukkan bahwa hanya faktor usia gestasi $(\mathrm{p}=0,006)(\mathrm{OR}=6,198 ; \mathrm{CI} 95 \%=1,61-27,88)$ dan LILA $(\mathrm{p}=0,018)$ $(\mathrm{OR}=6,623$; CI 95\%=1,327-51,2) yang berhubungan signifikan dengan kejadian BBLR. Dapat disimpulkan bahwa ibu hamil yang melahirkan bayi prematur berisiko 6,2 kali lebih besar untuk mengalami BBLR, sedangkan ibu hamil yang KEK berisiko 6,6 kali lebih besar untuk mengalami BBLR.
\end{abstract}

Kata kunci: BBLR, hemoglobin, LILA, usia gestasi

\begin{abstract}
Low Birth Weight $(L B W)$ is one of the biggest causes of neonatal mortality in Indonesia. The prevalence of $L B W$ at Semampir District in Surabaya tended to increase from 5.74\% in 2013 to 13.65\% in 2015. LBW caused by multifactors including internal factors such as fetal, placental and maternal, and also external factors such as lifestyle and environment. This study aimed to analyze the association between maternal age, gestational age, Mid Upper-Arm Circumference (MUAC), Hemoglobin (Hb) levels, environmental tobacco exposure and LBW at Semampir District, Surabaya. The respondents were mothers at Semampir District who gave birth in 2016. The design of this study was case control. The sample consisted of 22 mothers from the control group and 22 mothers from the case group. The result of descriptive analysis respectively showed that in case group (40.6\%) and control group (13.6\%) were not pregnant in healthy reproductive age. $59.1 \%$ and $18.1 \%$ gave birth when the gestational age $<37$ weeks. $41 \%$ and $9.1 \%$ were suffered of chronic energy malnutrition (MUAC <23.5). $40.9 \%$ and $22.7 \%$ were anemic. Moreover, $90.9 \%$ and $77.2 \%$ were exposed to tobacco smoke (secondhand smoke exposure). Chi square analysis with $\alpha=0.05$ showed that there were significance associations between gestational age ( $p=0.006)(O R=6.198 ; C I 95 \%=1.61-27.88)$ and MUAC $(p=0.018)$ $(O R=6.623 ; C I 95 \%=1327-51.2)$ with LBW. It is concluded that mother who gave birth to a premature baby were 6.2 times more likely to have $L B W$, whereas mother who suffered from chronic energy malnutrition were 6.6 times more likely to have $L B W$ baby.
\end{abstract}

Keywords: LBW, hemoglobin, MUAC, gestational age

Amima Fajriana, et al., MGI(2018) 71-80

DOI: 10.20473/mgi.v13i1.71-80. 


\section{PENDAHULUAN}

Sebesar $45 \%$ kematian anak di Indonesia terjadi pada masa neonatal atau bulan pertama kehidupan (UNICEF, 2012; Kemenkes, 2013). Di negara berkembang maupun maju, bayi dengan berat lahir rendah $(<2500$ gram $)$ merupakan salah satu faktor utama yang dapat memengaruhi kematian neonatal, kematian postneonatal maupun morbiditas pada anak (Mutthaya, 2009). Menurut Depkes (2008), Bayi Berat Lahir Rendah (BBLR) dapat disebabkan oleh kelahiran prematur $(<37$ minggu), bayi Kecil Masa Kehamilan (KMK) atau Small for Gestational Age (SGA), maupun kombinasi keduanya. Woo dan Albanese (2008) menambahkan bahwa KMK atau SGA dapat disebabkan oleh hambatan pertumbuhan janin atau karena faktor konstitusional seperti genetik, ras dan jenis kelamin. Semakin kecil umur kehamilan, maka berat lahir bayi juga semakin kecil karena secara fisiologis maupun anatomis organ yang ada di dalam tubuh janin belum berkembang secara sempurna sehingga risiko terhadap kesakitan bahkan kematian meningkat (WHO, 2004; Woo and Albanese, 2008). Pada BBLR akibat hambatan pertumbuhan janin, maka anak memiliki kemungkinan lebih besar dalam hidupnya untuk mengalami stunting, bahkan saat dewasa berisiko menderita penyakit kronis seperti hipertensi, diabetes, dan kardiovaskular (WHO, 2004). Selain itu terdapat beberapa masalah kesehatan lain yang disebabkan oleh BBLR antara lain asfiksia, hipotermi, infeksi, ikterus gangguan pemberian ASI dan sebagainya (Depkes, 2008).

Smitten (2011) menyebutkan bahwa BBLR yang terjadi akibat hambatan pertumbuhan dapat disebabkan oleh 3 faktor utama yaitu faktor janin, plasenta dan maternal, tetapi terjadinya hambatan pertumbuhan janin biasanya disebabkan oleh multifaktor. Ministry of Health Srilanka (2013) menambahkan bahwa BBLR dapat disebabkan oleh berbagai macam faktor internal dan eksternal mulai dari genetik (kelainan kromosom), psikososial (stress, depresi), dan kesehatan maternal (hipertensi, diabetes, infeksi). Kamariyah dan Musyarofah (2016) mengatakan bahwa gizi ibu sebelum dan saat hamil juga dapat memengaruhi berat lahir bayi, misalnya defisiensi zat gizi makro karena kekurangan energi kronis (LILA $<23,5 \mathrm{~cm}$ ).
Apabila ibu hamil mengalami KEK, maka janin tidak mendapatkan asupan gizi yang optimal, sehingga pertumbuhan dan perkembangan janin terganggu. LILA diikuti dengan pertambahan berat badan selama kehamilan adalah faktor yang penting yang dapat memengaruhi berat bayi saat lahir (Anggraini et al., 2014). Selain defisiensi zat gizi makro, kekurangan zat gizi mikro misalnya anemia $(\mathrm{Hb}<11)$ juga dapat berhubungan dengan hambatan pertumbuhan janin akibat kurangnya pasokan oksigen menuju janin (Sifakis dan Pharmakides, 2000). Faktor-faktor lainnya yaitu obstetri (kehamilan di usia remaja, paritas, jarak kehamilan), gaya hidup (merokok, alkohol) dan lingkungan (paparan asap rokok dan polusi) (Ministry of Health Srilanka, 2013). Efek yang diterima oleh ibu hamil perokok aktif dibanding ibu hamil perokok pasif tidak jauh berbeda (Crane et al., 2011). CO yang terhirup ibu hamil akan menghambat oksigen untuk berikatan dengan $\mathrm{Hb}$ sehingga dapat menyebabkan fetal hypoxia. Hipoksia janin yang terjadi secara terus menerus dapat pertumbuhan janin (Lippman, 2000).

Survei WHO pada tahun 2012 menyebutkan bahwa $15-20 \%$ bayi di dunia lahir dengan berat rendah. Di Indonesia, prevalensi BBLR dari tahun 2010-2013 cenderung menurun, yaitu dari 11,1\% menjadi 10,2\% (Balitbangkes, 2013). Pada tahun 2013, prevalensi BBLR di Provinsi Jawa Timur adalah sebesar 11\%, lebih besar jika dibandingkan dengan rata-rata prevalensi di Indonesia (Balitbangkes, 2013).

Kota Surabaya memiliki prevalensi BBLR yang tergolong rendah jika dibandingkan dengan kota lainnya di Jawa Timur. Selain itu, prevalensinya juga cenderung menurun dari tahun 2013-2016 yaitu sebesar 2,63\% menjadi 2,36\% (Dinkes Surabaya, 2014; 2015; 2016; 2017). Meskipun prevalensi BBLR di Surabaya tidak tergolong tinggi, namun berdasarkan data Dinkes Surabaya (2015), BBLR menjadi salah satu penyebab utama kematian bayi di Kota Surabaya. Penyebab kematian bayi lainnya adalah asfiksia dan kelainan kongenital.

Berdasarkan hasil laporan Dinkes Surabaya (sejak tahun 2014 hingga 2017) masalah BBLR banyak ditemukan di daerah Kecamatan Semampir. Prevalensi BBLR di Kecamatan Semampir pada 
tahun 2013 adalah sebesar 5,74\%, tahun 2014 sebesar $8,55 \%$ dan meningkat menjadi $13,65 \%$ di tahun 2015. Meskipun pada tahun 2016 prevalensinya turun menjadi $11,48 \%$, namun Kecamatan Semampir tetap menjadi salah satu daerah dengan prevalensi BBLR tertinggi di Surabaya. Melihat tingginya prevalensi BBLR di Kecamatan Semampir serta dampak yang mungkin ditimbulkan dari kejadian BBLR terhadap kesehatan anak, maka peneliti tertarik untuk mengidentifikasi karakteristik responden serta menganalisis hubungan antara faktor usia ibu saat hamil, usia gestasi, LILA, kadar hemoglobin $(\mathrm{Hb})$ dan status paparan asap rokok dengan kejadian BBLR di Kecamatan Semampir.

\section{METODE}

Jenis penelitian ini adalah observasional analitik dengan desain kasus kontrol. Melalui desain penelitian kasus kontrol, peneliti dapat melihat beberapa faktor risiko yang kemungkinan berhubungan dengan kejadian BBLR (Lapau, 2015). Penelitian ini telah dikaji dan lulus uji komite etik Fakultas Kesehatan Masyarakat Universitas Airlangga dengan nomor 360-KEPK.

Variabel terikat pada penelitian ini adalah BBLR, sedangkan variabel bebas terdiri atas usia ibu ketika hamil, usia gestasi (kehamilan), ukuran LILA, kadar $\mathrm{Hb}$, dan status paparan asap rokok. Data primer pada penelitian ini terdiri dari karakteristik responden, usia ibu saat hamil, dan status paparan asap rokok rumah tangga. Data sekunder yang diambil melalui buku Kesehatan Ibu dan Anak (KIA) antara lain data usia gestasi, ukuran LILA, dan kadar $\mathrm{Hb}$ saat hamil.

Populasi pada penelitian adalah semua ibu yang melahirkan bayi pada tahun 2016. Ibu merupakan masyarakat yang tinggal di wilayah Kecamatan Semampir, terdaftar dan memiliki data di salah satu Puskesmas Wonokusumo, Pegirian atau Sidotopo. Populasi ibu melahirkan di Kecamatan Semampir tahun 2016 berjumlah 1616 orang. Oleh karena menggunakan pendekatan kasus kontrol, maka populasi dan sampel penelitian dikategorikan menjadi 2 yaitu kelompok kasus dan kontrol. Sampel yang dibutuhkan sebesar 44 responden, dengan menggunakan perbandingan 1:1 maka besar sampel pada kelompok kontrol (berat lahir bayi normal) maupun kasus (berat lahir bayi rendah) masing-masing adalah 22 responden.

Pengambilan sampel dari masing-masing puskesmas diambil melalui metode proportional random sampling dengan matching tempat tinggal dari kelompok kasus. Responden yang menjadi sampel penelitian harus memenuhi beberapa kriteria inklusi seperti memiliki catatan pengukuran LILA dan kadar Hb pada buku KIA setidaknya satu kali selama kehamilan, melahirkan anak tunggal, ibu bukan perokok aktif serta bersedia menjadi subjek penelitian.

Analisis statistik yang digunakan untuk menguji hubungan antara variabel independen dengan variabel dependen adalah Chi square Yate's Correction dengan tingkat kemaknaan $p$-value $<0,05$ dan besar $\alpha=0,05$. Odd ratio (OR) atau besar risiko pada penelitian ini menggunakan nilai Confidence Interval sebesar 95\%.

\section{HASIL DAN PEMBAHASAN}

Usia ibu merupakan usia saat dilakukan wawancara. Pada Tabel 1. dapat dilihat bahwa hampir seluruh ibu pada kelompok kasus maupun kontrol berusia reproduktif sehat (20-35 tahun). Pada usia reproduktif sehat, ibu telah memiliki kesehatan reproduksi yang baik dan merupakan waktu yang ideal untuk menikah dan hamil (BKKBN, 2007).

Menurut Ohlsson dan Shah (2008), jenis kelamin bayi adalah salah satu faktor yang dapat memengaruhi berat badan bayi saat lahir. Hasil penelitian menunjukkan bahwa sebagian besar ibu pada kelompok kasus melahirkan bayi laki-laki, sedangkan ibu pada kelompok kontrol melahirkan bayi perempuan. Ohlsson dan Shah (2008) menambahkan bahwa bayi laki-laki memiliki kecenderungan untuk lahir prematur, sehingga dapat memengaruhi penurunan berat badan bayi saat lahir.

Berdasarkan hasil penelitian, sebagian besar ibu pada kelompok kasus memiliki jenjang pendidikan hingga SMA (54,5\%), sebaliknya hampir separuh ibu pada kelompok kontrol hanya memiliki jenjang pendidikan tamat SD $(36,3 \%)$. Meskipun hampir separuh ibu pada 
kelompok kontrol rata-rata memiliki pendidikan tamat SD, namun terdapat $9 \%$ ibu yang telah menempuh pendidikan hingga tamat Perguruan Tinggi. Institute for The Study of Labors (2007) menyebutkan bahwa ibu yang memiliki tingkat pendidikan tinggi kemungkinan memiliki income yang lebih tinggi sehingga bisa memenuhi kebutuhan dan dapat melakukan investasi terkait kesehatan. Selain itu, pendidikan yang tinggi menggambarkan wawasan yang luas sehingga semakin tinggi pendidikan maka akan semakin mudah dalam menerima pengetahuan baru yang berhubungan dengan kesehatan maupun kehamilannya (Simanjuntak, 2009).

Rata-rata ibu merupakan ibu rumah tangga, meskipun berdasarkan Tabel 1. dapat diketahui bahwa sebaran jenis pekerjaan ibu pada kelompok kasus lebih bervariasi. Pekerjaan berkaitan dengan ekonomi dan aktivitas fisik ibu selama hamil. Pekerjaan yang melelahkan dan mengangkat benda yang berat selama kehamilan merupakan aktivitas yang harus dihindari. Ibu harus mendapat waktu istirahat yang cukup (Depkes RI, 2006).
Sebesar 36,3\% tingkat pendapatan keluarga ibu pada kelompok kasus berada pada rentang kuartil 4 (Rp.3000.001-Rp.8000.000), sedangkan $45,4 \%$ ibu pada kelompok kontrol memiliki pendapatan keluarga yang tergolong rendah yaitu pada rentang kuartil 1 (Rp.700.000-Rp.1500.000). Menurut Miller dan Rogers (2009), besarnya pendapatan memengaruhi kualitas kesehatan dan gizi ibu selama kehamilan. Selain itu, keluarga dengan status ekonomi yang rendah cenderung tinggal di lingkungan dan fasilitas rumah yang kurang baik dan tidak memadai dan merupakan faktor yang memengaruhi kesehatan ibu dan keluarga.

Pada Tabel 2. terdapat gambaran distribusi frekuensi variabel usia ibu ketika hamil, usia kehamilan (gestasi), ukuran LILA, kadar $\mathrm{Hb}$ dan status paparan asap rokok. Selain itu, pada Tabel 2. juga dapat diketahui hubungan (p-value) serta besar faktor risiko (odd ratio) antara variabel bebas dengan variabel terikat (BBLR).

Variabel bebas yang pertama adalah usia ibu saat hamil. Hasil analisis hubungan antara

Tabel 1. Distribusi Frekuensi Karakteristik Responden Berdasarkan Usia Ibu, Jenis Kelamin Bayi, Tingkat Pendidikan, Jenis Pekerjaan dan Tingkat Pendapatan

\begin{tabular}{|c|c|c|c|c|}
\hline \multirow{2}{*}{ Variabel } & \multicolumn{2}{|c|}{ Kasus } & \multicolumn{2}{|c|}{ Kontrol } \\
\hline & $\mathbf{n}$ & $\%$ & n & $\%$ \\
\hline \multicolumn{5}{|l|}{ Usia Ibu } \\
\hline$<20$ tahun & 2 & 9,0 & 0 & 0,0 \\
\hline 20-35 tahun & 17 & 77,2 & 17 & 77,2 \\
\hline$>35$ tahun & 3 & 13,6 & 5 & 22,7 \\
\hline \multicolumn{5}{|l|}{ Jenis Kelamin Bayi } \\
\hline Laki-laki & 12 & 54,5 & 8 & 36,3 \\
\hline Perempuan & 10 & 45,4 & 14 & 63,6 \\
\hline \multicolumn{5}{|l|}{ Tingkat Pendidikan } \\
\hline Tidak tamat SD & 1 & 4,5 & 1 & 4,5 \\
\hline Tamat SD (Sekolah Dasar) & 4 & 18,1 & 8 & 36,3 \\
\hline Tamat SMP (Sekolah Menengah Pertama) & 5 & 22,7 & 5 & 22,7 \\
\hline Tamat SMA (Sekolah Menengah Atas) & 12 & 54,5 & 6 & 27,2 \\
\hline Tamat PT (Perguruan Tinggi) & 0 & 0,0 & 2 & 9,0 \\
\hline \multicolumn{5}{|l|}{ Jenis Pekerjaan } \\
\hline Ibu rumah tangga & 12 & 54,5 & 20 & 90,9 \\
\hline Pedagang & 2 & 9,0 & 2 & 4,5 \\
\hline Pegawai swasta & 7 & 31,8 & 0 & 0,0 \\
\hline Lain-lain & 1 & 4,5 & 0 & 0,0 \\
\hline \multicolumn{5}{|l|}{ Pendapatan Keluarga } \\
\hline Kuartil 1 Rp.7.00.000-Rp.1.500.000 & 6 & 27,2 & 10 & 45,4 \\
\hline Kuartil 2 Rp.1.500.001-Rp.2.000.000 & 4 & 18,1 & 5 & 22,7 \\
\hline Kuartil 3 Rp.2.000.001-Rp.3.000.000 & 4 & 18,1 & 5 & 22,7 \\
\hline Kuartil 4 Rp.3.000.001-Rp.8.000.000 & 8 & 36,3 & 2 & 4,5 \\
\hline Total & 22 & 100,0 & 22 & 100,0 \\
\hline
\end{tabular}


usia ibu saat hamil dan BBLR menunjukkan bahwa tidak terdapat hubungan yang signifikan $(\mathrm{p}=0,052)$ diantara keduanya. Usia ibu saat hamil tidak berhubungan dengan BBLR di Kecamatan Semampir disebabkan oleh sebagian besar ibu dari kedua kelompok hamil di usia 20-35 tahun. Serupa dengan penelitian yang dilakukan oleh Purwanto dan Wahyuni (2016) yang menyebutkan bahwa tidak terdapat hubungan yang signifikan antara usia ibu ketika hamil dengan kejadian BBLR. Hasil penelitian dengan metode literature review yang dilakukan oleh Aras (2013) menyimpulkan bahwa kehamilan di usia ekstrem $(<20$ tahun atau $>40$ tahun) merupakan faktor risiko terhadap kelahiran prematur dan BBLR, namun perbedaan ras dan sosial ekonomi merupakan faktor perancu antara usia ibu saat hamil dengan menurunnya berat bayi saat lahir. Menurut Aliyu, et al (2012), secara umum usia berhubungan dengan kematangan sistem reproduksi seorang wanita. Kehamilan di usia terlalu muda menyebabkan secara biologis kondisi rahim dan panggul ibu belum berkembang secara sempurna (BKKBN, 2007). Hal tersebut menyebabkan aliran darah menuju serviks dan rahim berkurang, sehingga asupan gizi untuk janin juga berkurang. Ibu yang hamil di usia remaja masih mengalami masa pertumbuhan, sehingga terjadi ketidakseimbangan distribusi gizi bagi ibu dan janin. Pada akhirnya, tubuh kesulitan untuk memenuhi gizi bagi ibu maupun janin. Kekurangan gizi selama kehamilan dapat menghambat pertumbuhan janin sehingga berat lahir bayi akan berkurang (Ohlsson dan Shah, 2008). Selain kehamilan di usia muda, hamil di usia tua juga termasuk berisiko karena semakin tua usia ibu maka kemungkinan munculnya komplikasi seperti hipertensi, aterosklerosis dan diabetes juga semakin meningkat (Ohlsson dan Shah, 2008). Misalnya, jika ibu yang sedang hamil menderita aterosklerosis, maka dapat menimbulkan penyempitan dan pengerasan pembuluh darah menuju endometrium sehingga suplai zat gizi ke janin dapat terganggu (Cunningham, et al., 2005). Selain itu, fungsi rahim seorang ibu yang berusia $>35$ tahun juga sudah mulai menurun (BKKBN, 2007).

Berdasarkan Tabel 2. diketahui bahwa 59\% ibu pada kelompok kasus melahirkan bayi ketika usia janin 26-36 minggu (prematur), sebaliknya bayi yang lahir di usia kehamilan 37-42 minggu didominasi oleh ibu pada kelompok kontrol. Hasil analisis menunjukkan bahwa terdapat hubungan yang signifikan $(\mathrm{p}=0,006)$ antara usia gestasi dengan kejadian BBLR di Kecamatan Semampir, Surabaya. Selain itu, didapatkan juga nilai OR sebesar 6,198 yang artinya ibu yang melahirkan bayi prematur hampir 6,2 kali lebih besar untuk melahirkan BBLR. Penelitian ini didukung oleh beberapa studi lain yang pernah dilakukan oleh Sutan, et al. (2014) di Malaysia yang mengatakan bahwa prematur merupakan faktor risiko kejadian BBLR. Ibu yang melahirkan bayi prematur memiliki risiko 2,4 kali lebih besar untuk melahirkan bayi dengan berat rendah. Kelahiran prematur merupakan salah satu faktor utama yang langsung dapat menyebabkan BBLR (Smitten, 2011). Pada trimester pertama, organ tubuh seperti jantung, liver, ginjal, otak, dan saraf mulai terbentuk. Setelah itu, pada trimester kedua, mulai terjadi pertumbuhan panjang dan berat badan. Pada trimester ketiga, bayi mulai bisa bergerak dan pertumbuhan panjang serta pertambahan berat badan terus berlangsung (Johns Hopkins University, 2017). Secara biologis, semakin bertambahnya usia kehamilan, maka pertumbuhan dan perkembangan janin juga semakin meningkat, sehingga apabila bayi lahir sebelum usia gestasi yang seharusnya (37-42 minggu) maka panjang dan berat badan bayi belum bertambah secara maksimal (Manuaba, 2010).

Variabel bebas selanjutnya yang diteliti pada penelitian ini adalah Lingkar Lengan Atas ( LILA). Menurut Tang, et al. (2016), pengukuran antropometri LILA merupakan indikator lemak subkutan dan otot sehingga dapat digunakan untuk mengetahui cadangan protein di dalam tubuh. Ukuran LILA dapat digunakan sebagai indikator Protein Energy Malnutrition (PEM) pada anak-anak serta mengetahui risiko Kekurangan Energi Kronis (KEK) pada wanita usia subur (Gibson 2005; Kamariyah \& Musyarofah, 2016). Selain itu, pengukuran status gizi dengan metode LILA merupakan metode yang murah serta cocok digunakan di negara berkembang (Tang, et al., 2016). Berdasarkan hasil penelitian, diketahui bahwa pada kelompok kasus maupun 
kelompok kontrol, keduanya didominasi oleh ibu yang tidak termasuk KEK, meskipun proporsi diantara keduanya jauh berbeda. Pada kelompok kasus, 41\% ibu tergolong KEK, sedangkan pada kelompok kontrol persentasenya sebesar 9,1\%. Setelah dilakukan uji hubungan antara LILA dengan BBLR, diketahui bahwa nilai $\mathrm{p}=0,018$, sehingga $\mathrm{p}<\alpha$ maka dapat disimpulkan bahwa ibu yang tergolong $\operatorname{KEK}(<23,5)$ berisiko 6,6 kali lebih besar untuk mengalami BBLR. Sesuai dengan penelitian yang dilakukan oleh Anggraini et al. (2014) yang menyimpulkan bahwa LILA dan BBLR memiliki hubungan yang signifikan. Selain itu, ibu yang memiliki LILA $<23,5$ berisiko 4,3 kali lebih besar untuk mengalami BBLR. Menurut Ohlsson dan Shah (2008), ibu yang tergolong KEK mengalami kekurangan energi dalam waktu yang lama, bahkan sejak sebelum masa kehamilan. Asupan gizi yang tidak adekuat saat masa implantasi embrio dapat berakibat fatal bagi perkembangan janin di trimester selanjutnya. Padahal, sebelum dan saat hamil, ibu membutuhkan asupan gizi yang optimal untuk mempersiapkan dan menunjang pertumbuhan serta perkembangan janin, sehingga jika ibu mengalami kekurangan gizi maka asupan gizi yang diberikan untuk janin juga akan sulit untuk terpenuhi, akibatnya terjadi hambatan pertumbuhan janin dan berat bayi lahir yang rendah. Meskipun LILA dapat dijadikan salah satu faktor, tetapi menurut Anggraini, et al. (2014), ibu yang diawal kehamilan memiliki LILA maupun IMT yang normal tetapi tidak diikuti dengan pertambahan berat badan yang seharusnya, maka ibu tersebut juga berisiko untuk mengalami BBLR. Selain itu, menurut Assefa, et al. (2012), kekurangan energi kronis maupun akut memiliki hubungan dan pengaruh dengan berat lahir bayi, namun kekurangan energi akut memiliki efek yang lebih nyata dibandingkan dengan kekurangan energi kronis.

Pengukuran kadar $\mathrm{Hb}$ merupakan salah satu indikator terkait gizi yang dapat digunakan untuk mengetahui kejadian anemia (WHO, 2000). Anemia dapat memengaruhi pertumbuhan dan perkembangan janin saat hamil maupun setelahnya (Kemenkes RI, 2016). Berdasarkan hasil penelitian diketahui bahwa mayoritas ibu dari kelompok kasus dan kontrol tidak mengalami anemia saat hamil. Setelah dilakukan analisis hubungan, didapatkan nilai $\mathrm{p}=0,217$ sehingga $\mathrm{p}>\alpha$, maka dapat disimpulkan bahwa tidak ada hubungan yang signifikan antara anemia pada ibu hamil dengan kejadian BBLR di Kecamatan Semampir. Hasil penelitian yang tidak signifikan disebabkan karena sebagian besar ibu tidak mengalami anemia.

Selain itu, pada penelitian ini, kadar Hb yang diteliti tidak diambil dari salah satu trimester atau dapat dikatakan waktu pemeriksaan kadar $\mathrm{Hb}$

Tabel 2. Hasil Analisis Statistik Hubungan antara Usia Ibu saat Hamil, Usia Gestasi, LILA, kadar Hb dan Status Paparan Asap Rokok dengan BBLR

\begin{tabular}{|c|c|c|c|c|c|c|c|}
\hline \multirow{2}{*}{ Variabel } & \multicolumn{2}{|c|}{ Kasus } & \multicolumn{2}{|c|}{ Kontrol } & \multicolumn{3}{|c|}{ Nilai } \\
\hline & $\mathbf{n}$ & $\%$ & $\mathbf{n}$ & $\%$ & p value & OR & CI $95 \%$ \\
\hline \multicolumn{8}{|l|}{ Usia Saat Hamil } \\
\hline$<20$ tahun atau $>35$ tahun & 9 & 40,6 & 3 & 13,6 & \multirow{2}{*}{0,052} & \multirow{2}{*}{4,236} & \multirow{2}{*}{$0,988-22,69$} \\
\hline $20-35$ tahun & 13 & 59,1 & 19 & 86,4 & & & \\
\hline \multicolumn{8}{|l|}{ Usia Gestasi } \\
\hline Preterm (28-36 minggu) & 13 & 59,0 & 4 & 18,1 & \multirow{2}{*}{0,006} & \multirow{2}{*}{6,198} & \multirow{2}{*}{$1,61-27,88$} \\
\hline Full term (37-42 minggu) & 9 & 40,9 & 18 & 81,8 & & & \\
\hline \multicolumn{8}{|l|}{ LILA } \\
\hline $\operatorname{KEK}(<23,5)$ & 9 & 41 & 2 & 9,1 & \multirow{2}{*}{0,018} & \multirow{2}{*}{6,623} & \multirow{2}{*}{$1,327-51,2$} \\
\hline Tidak KEK $(\geq 23,5)$ & 13 & 59 & 20 & 90,9 & & & \\
\hline \multicolumn{8}{|l|}{ Kadar Hb } \\
\hline Anemia $(<11 \mathrm{~g} / \mathrm{dl})$ & 9 & 40,9 & 5 & 22,7 & \multirow{2}{*}{0,217} & \multirow{2}{*}{2,308} & \multirow{2}{*}{$0,618-9,30$} \\
\hline Tidak anemia $(\geq 11 \mathrm{~g} / \mathrm{dl})$ & 13 & 59,1 & 17 & 77,3 & & & \\
\hline \multicolumn{8}{|l|}{ Status Paparan Asap Rokok } \\
\hline Ya & 20 & 90,9 & 17 & 77,2 & \multirow{3}{*}{0,253} & \multirow{3}{*}{2,872} & \multirow{3}{*}{$0,498-23,72$} \\
\hline Tidak & 2 & 9,1 & 5 & 22,7 & & & \\
\hline & 22 & 100 & 22 & 100 & & & \\
\hline
\end{tabular}


antar responden tidak homogen. Pada penelitian terkait kadar $\mathrm{Hb}$ dan BBLR yang dilakukan oleh Bakacak, et al. (2014) dituliskan bahwa hanya pada trimester pertama saja kadar $\mathrm{Hb}$ yang rendah berhubungan dengan kejadian BBLR, sedangkan menurut penelitian yang dilakukan oleh Kumar, et al. (2013) mengatakan bahwa ibu yang mengalami anemia pada trimester ketiga memiliki hubungan yang lebih signifikan dengan kejadian BBLR jika dibandingkan dengan ibu yang mengalami anemia di trimester pertama atau kedua. Sebuah penelitian yang dilakukan oleh Masukume, et al. (2015) mengatakan bahwa anemia tidak berhubungan signifikan dengan birth outcome seperti kelahiran prematur, SGA dan BBLR. Masukume, et al. (2015) menambahkan bahwa meskipun hubungannya tidak signifikan, tetapi masalah terkait outcome kehamilan cenderung lebih sering muncul pada ibu yang anemia dibandingkan dengan yang tidak anemia. Sebaliknya, penelitian yang dilakukan di Iran oleh Tabrizi dan Barjasteh (2015) menyimpulkan hal sebaliknya yaitu jika konsentrasi $\mathrm{Hb}$ pada trimester pertama, kedua maupun ketiga berhubungan dengan berat lahir bayi dan kejadian BBLR karena $\mathrm{Hb}$ yang rendah (anemia) dapat memicu terjadinya hambatan pertumbuhan janin. Menurut Mutthaya (2009), sebagian besar kejadian anemia pada ibu hamil disebabkan oleh defisiensi zat besi (Fe). Mutthaya (2009) juga menambahkan bahwa mekanisme anemia dapat memengaruhi berat lahir dapat dijelaskan oleh beberapa keadaan, yaitu (i) kurangnya Fe dapat mengganggu sistem imun yang kemudian dapat meningkatkan kerawanan tubuh terhadap infeksi penyakit misalnya genital infection, urinary tract infection, malaria, hepatitis. Selain itu, (ii) defisiensi $\mathrm{Fe}$ dapat meningkatkan produksi hormon stress norepinephrine dan cortisol. Kadar $\mathrm{Hb}$ yang rendah juga dapat mengakibatkan (iii) fetal hypoxia yang kemudian merangsang tubuh untuk memproduksi hormon corticotrophine. Hormon tersebut dapat memengaruhi plasenta dengan menurunkan aliran darah menuju janin. Jika terjadi secara terus menerus, akibatnya janin akan mengalami hambatan pertumbuhan dan ibu berisiko untuk melahirkan BBLR.

Berdasarkan Tabel 2. dapat dilihat bahwa hampir semua ibu pada kelompok kasus maupun kontrol terpapar asap rokok saat hamil. Pada kelompok kasus persentasenya mencapai 91\%, sedangkan pada kelompok kontrol besarnya mencapai 77,2\%. Hasil analisis hubungan menunjukkan bahwa tidak terdapat hubungan yang signifikan $(\mathrm{p}=0,253)$ antara paparan asap rokok dengan BBLR di Kecamatan Semampir. Hasil yang tidak berhubungan kemungkinan disebabkan karena ibu hamil hanya terpapar asap rokok dalam jumlah yang sedikit dan frekuensinya tidak terlalu sering. Pada penelitian lain terkait paparan asap rokok yang dilakukan oleh Wahabi, et al. (2013) menyatakan bahwa tidak terdapat perbedaan yang signifikan antara bayi yang lahir dari ibu hamil perokok pasif dan bukan perokok pasif, namun pada bayi yang lahir dari ibu yang terpapar asap rokok memiliki berat yang memang lebih rendah (-35gram) dibandingkan ibu yang tidak terpapar asap rokok. Hasil ini tidak sesuai dengan penelitian yang dilakukan oleh Reza dan Puspitasari (2014) karena menurut penelitian tersebut, hubungan antara keterpaparan asap rokok dengan kejadian BBLR adalah signifikan. Bahkan, ibu yang terpapar asap rokok selama kehamilan berisiko 2,9 kali lebih besar untuk mengalami BBLR. Rokok mengandung bahan kimia berbahaya seperti nikotin, kotinin dan karbonmonoksida yang apabila dihirup oleh orang lain juga bisa menyebabkan gangguan kesehatan (Abu-Baker, et al., 2010). Nikotin pada rokok memiliki sifat vasoaktif karena dapat memengaruhi konstriksi dan dilatasi pembuluh darah. Nikotin yang masuk ke dalam plasenta akan menurunkan sirkulasi darah menuju janin. Apabila sirkulasi darah menuju janin rendah, maka pasokan zat gizi untuk pertumbuhan janin juga akan terhambat (Ohlsson dan Shah, 2008). Di samping itu, zat karbonmonoksida (CO) yang terhirup dan masuk ke dalam tubuh akan mengikat $\mathrm{Hb}$ dan pada akhirnya mengakibatkan chronic fetal hypoxia (Lippman, 2000). Fetal hypoxia kronis dapat mengakibatkan janin kekurangan zat gizi dan oksigen, sehingga pada akhirnya bayi juga 
mengalami gangguan pertumbuhan (Lippman, 2000).

\section{KESIMPULAN DAN SARAN}

Tidak terdapat hubungan yang signifikan antara usia ibu saat hamil, kadar $\mathrm{Hb}$ dan status paparan asap rokok dengan kejadian BBLR, tetapi diketahui bahwa ada hubungan yang signifikan antara usia gestasi dan LILA dengan kejadian BBLR di Kecamatan Semampir. Bahkan, ibu yang melahirkan bayi $<37$ minggu berisiko hampir 6,2 kali lebih besar untuk melahirkan BBLR. Selain itu, dapat diketahui juga bahwa ibu yang tergolong KEK berisiko 6,6 kali lebih besar untuk mengalami BBLR.

Saran yang dapat diberikan untuk mencegah prematur yaitu ibu hamil sebaiknya rutin memeriksakan kehamilan minimal 4 kali selama hamil untuk mencegah terjadinya komplikasi yang akan berdampak langsung pada kelahiran prematur. Saran untuk mencegah KEK dan risiko BBLR pada ibu hamil yaitu dengan meningkatkan kualitas jenis makanan berprotein seperti susu, ikan, kacangkacangan dan sayuran hijau. Saran bagi Puskesmas terkait adalah dengan melakukan skrining kesehatan pada ibu hamil serta memberikan makanan padat gizi pada ibu yang tergolong KEK dan berasal dari keluarga miskin.

\section{DAFTAR PUSTAKA}

Abu-Baker, N.N., Haddad, L., \& Savage, C. (2010). The influence of secondhand soke exposure on birth outcomes in Jordan. International Journal of Environmental Research and Public Health, 7, 616-634. Diakses dari: < https://www.ncbi. nlm.nih.gov/pmc/articles/PMC2872296/>.

Anggraini, D., Adityawarman, Utomo, B., \& Suryawan, A. (2014). Risk Factor of Low Birth Weight (LBW), a Case Control Study. Folia Medica Indonesiana, [e-journal] 50(4). 270-277. Diakses dari: <http://journal.unair. ac.id/download-fullpapers fmi90872afb19full. pdf $>$.

Aliyu, M.H., Luke, S., Kristensen, S., Alio, A.P., \& Salihu, H.M. (2012). The factor list of low birth weight: a population based study In Karachi. $J$
Adolesc Health, 46. 77-82. Diakses dari: <www. jahonline.org $>$.

Aras, R.Y. (2013). Is maternal age risk factor for low birth weight. Archieve of medicine and health science, [e-journal] 1(1), pp. 33-37. Diakses dari: <http://www.amhsjournal.org/ article.asp?issn=2321-4848; year=2013; volume $=1$; issue $=1$; spage $=33$; epage $=37$; aulast $=$ Aras $>$.

Assefa, N., Berhane, Y., \& Worku, A. (2012). Wealth status, mid upper arm circumference (MUAC) and antenatal care (ANC) are determinants for low birth weight in Kersa, Ethiopia. PLOS ONE, 7(6) e39957. Diakses dari: <journals. plos.org/plosone/article? id=10.1371/journal. pone.0039957>.

Badan Koordinasi Keluarga Berencana Nasional. (2007). Hindari kehamilan 4 terlalu. [pdf] Direktorat Kelangsungan Hidup Ibu, Bayi dan Anak. Tersedia di: <www.nad.bkkbn.go.id/data/ Documents/4\%20terlalu.pdf $>$.

Bakacak, M., Avci, F., Ercan, O., Kostu, B., Serin, S., Kiran, G., Bostanci, M.S., \& Bakacak, Z. (2014). The effect of maternal hemoglobin concentration on fetal birth weight according to trimesters. The Journal of Maternal Fetal and Neonatal Medicine, [e-journal] 28(17). Diakses dari: < https://www.ncbi.nlm.nih.gov/ pubmed/25338012>.

Balitbangkes. (2013). Riset kesehatan dasar (Riskesdas) 2013. Jakarta: Balitbangkes.

Cunningham, F.G., Leveno, K.J., Bloom, S.L., Hauth, J.C., Gilstrap III, L.C., \& Wenstrom, K.D. (2005). Williams obstetrics. $22^{\text {nd }}$ edition. New York: McGraw Hill.

Crane, J. M.G., Keough, M., Murphy P., Burrage, L. \& Hutchens, D. (2011). Effects of environmental tobacco smoke on perinatal outcomes: a retrospective cohort study. An International Journal of Obstetrics and Gynaecology, [ejournal] 118 (7), 865-871. Diakses dari: $<$ http://doi.org/10.111/j.1471-0528.2011.02941. $\mathrm{x}>$.

Departemen Kesehatan Republik Indonesia. (2006). Ibu sehat bayi sehat. Jakarta: Pusat Penyuluhan Kesehatan Masyarakat.

Departemen Kesehatan Republik Indonesia. (2008). Modul manajemen bayi berat lahir rendah (BBLR) untuk bidan di desa. Jakarta: Direktorat Jenderal Bina Kesehatan Masyarakat. 
Dinas Kesehatan Kota Surabaya. (2014). Laporan tahunan dinas kesehatan kota surabaya 2013. Surabaya: Dinas Kesehatan Kota Surabaya.

Dinas Kesehatan Kota Surabaya. (2015). Laporan tahunan dinas kesehatan kota surabaya 2014. Surabaya: Dinas Kesehatan Kota Surabaya.

Dinas Kesehatan Kota Surabaya. (2016). Laporan tahunan dinas kesehatan kota surabaya 2015. Surabaya: Dinas Kesehatan Kota Surabaya.

Dinas Kesehatan Kota Surabaya. (2017). Laporan tahunan dinas kesehatan kota surabaya 2016. Surabaya: Dinas Kesehatan Kota Surabaya.

Gibson, R.S. (2005). Principles of nutritional assessment. $2^{\text {nd }}$ edition. New York: Oxford University Press.

Institute for The Study of Labors. (2007). Mother's education and birth weight (Discussion Paper No. 2640). Bonn, Germany: Arnauld Chevalier and Vincent O'Sullivan.

Johns Hopkins University. (2017). Pregnancy: first trimester, second trimester, third trimester. Diakses dari: <http://www.hopkinsmedicine. org/healthlibrary/conditions/pregnancy_and_ childbirth/second_trimester_85,P01234>.

Kamariyah, N \& Musyarofah. (2016). Lingkar lengan atas akan memengaruhi pertambahan berat badan bayi lahir di BPS ardiningsih Surabaya. Jurnal Ilmiah Kesehatan, 9(1), pp. 98-105. Diakses dari: < http://journal.unusa. ac.id/index.php/jhs/article/view/92>.

Kumar, K.J., Asha, N., Murthy, D.S. \& Manjunath, V.G. (2013). Maternal anemia in various trimester and its effect on newborn weight and maturity: An Observational Study. International Journal of Preventive Medicine, 4(2), 193-199. Diakses dari: <https://www.ncbi.nlm.nih.gov/ pmc/articles/PMC3604852/>.

Kementerian Kesehatan Republik Indonesia. (2013). Profil kesehatan indonesia. Jakarta: Pusat Data dan Informasi dan Kesehatan.

Kementerian Kesehatan Republik Indonesia. (2016). Buku kesehatan ibu dan anak. Jakarta: Pusat Data dan Informasi Kesehatan.

Lapau, B. (2015). Metodologi penelitian kebidanan. Jakarta: Pustaka Obor Indonesia.

Lippman, M. (2000). Environmental toxicans. $2^{\text {nd }}$ edition. New York: John Wiley \& Sons, Inc.

Manuaba, I.B. (2010). Ilmu kebidanan, penyakit kandungan dan keluarga berencana untuk pendidikan bidan. Jakarta: Penerbit Buku Kedokteran EGC.
Masukume, G., Khashan, A.S., Kenny, L.C., Baker, P. N., Nelson, G., \& SCOPE consortium. (2015). Risk factors and birth outcomes of anemia in early pregnancy in a nulliparous cohort. PLOS, 10(4), e0122729. https://doi.org/10.1371/ journal.pone. 0122729 .

Miller, J.E., \& Rogers, Y.V. (2009). Mother's education and children's nutritional status: new evidence from Cambodia. Asian Development Reviews. 26(1),pp. 131-165. Diakses dari: $<$ http://citeseerx.ist.psu.edu/viewdoc/downloa d?doi=10.1.1.215.534\&rep=rep1\&type=pdf $>$.

Ministry of Health Srilanka. (2013). Strategies to promote optimal fetal growth and to minimize the prevalence of low birth weight in Srilanka: Health Sector Response. Thalawathugoda: Ministry of Health Srilanka.

Mutthaya, S. (2009). Maternal nutrition and low birth weight-what is really important? The Indian Journal and Medical Research. 130, 600-608. Diakses dari: $<$ https://www.ncbi.nlm. nih.gov/pubmed/20090114>.

Ohlsson, A., \& Shah, P. (2008). Determinant and prevention of low birth weight: a synopsis of the evidence. Alberta Canada: Institute of Health Economics.

Purwanto, A.D., \& Wahyuni, C.U. (2016). Hubungan antara umur kehamilan, kehamilan ganda, hipertensi dan anemia dengan kejadian bayi berat lahir rendah (BBLR). Jurnal Berkala Epidemiologi, [e-journal] 4(3), 349-359. Diakses dari: $<$ http://ejournal.unair.ac.id/index. php/JBE/article/viewFile/1627/2555>.

Reza, C., \& Puspitasari, N. (2014). Determinan bayi dengan berat lahir rendah. Jurnal Biometrika dan Kependudukan, 3(2), 96-106. Diakses dari: $<$ http://journal.unair.ac.id/download-fullpapersbiometrik3072387889full.pdf>.

Sifakis, S \& Pharmakides, G. (2000). Anemia in pregnancy. Annals of The New York Academy of Sciences, 900.125-136. Diakses dari: < http:// onlinelibrary.wiley.com/woll/doi/10.1111/ j.1749-6632.2000.tb06223.x/full>.

Simanjuntak, N.A. (2009). Hubungan anemia pada ibu hamil dengan kejadian bayi berat lahir rendah (BBLR) di badan pengelola rumah sakit umum (BPRSU) Rantauprapat Kabupaten Labuhan Batu Tahun 2008. (Skripsi Universitas Sumatera Utara, Sumatra Utara) Diakses dari: < https://www.researchgate.net/ publication/42356153>. 
Smitten, J. (2011). Approach to the child with IUGR/SGA. [online] Diakses dari: <http:// learn.pediatrics.ubc.ca/body-systems/neonate/ approach-to-the-child-with-iugrsga/>.

Sutan, M., Mohtar, M., Mahat, A.N., \& Tamil, A.M. (2014). Determinant of low birth weight infant: a matched case control study. Open Journal of Preventive Medicine, 4. 91-99. Diakses dari: $<$ http://file.scirp.org/Html/1-1340268_43684. $\mathrm{htm}>$.

Tabrizi, F.M., \& Barjasteh, S. (2015). Maternal hemoglobin levels during pregnancy and their association with birth weight of neonates. Iranian Journal of Pediatric and Hematology Ontology, 5(4). 211-217. Diakses dari: < https://www.ncbi.nlm.nih.gov/pmc/articles/ PMC4779156/>.

Tang, A.M., Chung, M., Dong, K., Terrin, N., Edmonds, A., Assefa, N., Chetty, T., Ramlal, R., Christian, P., West, K., Janjua, N., Wanke, C., Deitchler, M. \& Manasseh, Z.M. (2016). Determining a global mid-upper arm circumference cutoff to assess malnutrition in pregnant women. Washington DC: Food and Nutrition Technical Assistance III Project (FANTA). Diakses dari: < https://www. fantaproject.org/sites/default/files/resources/ FANTA-MUAC-cutoffs-pregnant-womenJune2016.pdfs.
UNICEF Indonesia. (2012). Ringkasan kajian kesehatan ibu dan anak. Diakses dari: $<\mathrm{https}: / /$ www.unicef.org/indonesia/id/A5_-_B_ Ringkasan_Kajian_Kesehatan_REV.pdf $>$.

Wahabi, H.A., Alzeidan, R.A., Fayed, A.A., Mandil, A., Al-Shaikh, G. \& Esmail, S.A. (2013). Effects secondhand smoke on the birth weight of term infants and the demographic profile of Saudi exposed women. BMC Public Health, 13(341). 1-6. Diakses dari: < https://bmcpublichealth. biomedcentral.com/articles/10.1186/14712458-13-341>.

WHO. (2000). The Asia-Pacific perspective: redefining obesity and its treatment. Geneva: WHO Pacific Region.

WHO. (2004). Appropriate body mass index for asian populations and its implications for policy and intervention strategies. The Lancet 363 (9403). 157-163.

WHO. (2012). Global Nutrition Targets 2025: Low birth weight policy briefs (WHO/NMH/ NHD/14.5). Geneva: Department of Nutrition for Health and Development.

Woo, R.K. \& Albanese, C.T. (2008). Pediatric Surgery, dalam Surgery basic science and clinical evidence. J.A. Norton, P.S. Barie, R.R. Bollinger, A.E. Chang, S.F.L. Ry, S.J. Mulvihill, H.I. Pass and R.W. Thimpson, editors. New York: Springer. 